Dikirim: 12 Juni 2017 Diterbitkan: 1 November 2017

\section{Faktor yang memengaruhi kualitas hidup orang dengan HIV/AIDS di Kota Kupang}

\section{Factors affecting quality of life of people living with HIV/AIDS in Kupang}

Fitri Handayani ${ }^{1}$, Fatwa Sari Tetra Dewi

\begin{abstract}
Purpose: This study aimed to determine factors that affect the quality of life of people living with HIV/AIDS (PLWHA) in Kota Kupang. Methods: The study used cross sectional study design with 100 people who had been on ARV therapy $\geq 1$ months, age $\geq 18$ years, was able to communicate with Indonesian language and willing to become respondents. The bivariate analysis used chi square test and multivariate analysis used logistic regression test. Results: There was no significant correlation between the level of education, duration of antiretroviral therapy and the stigma of the quality of life of PLWHA. There was no significant relationship between sex, age, occupation, income, marital status, and adherence to the quality of life of PLWHA. The factors that most affect the quality of life of PLWHA were education level and stigma of ARV therapy. Conclusion: The factors that most affect the quality of life of people living with HIV were education level and stigma of ARV therapy.
\end{abstract}

Keywords: duration of antiretroviral therapy; stigma; quality of life; people living with HIV/AIDS

\footnotetext{
${ }^{1}$ Poltekes Kemenkes Kupang (Email: fitrihaaandayani@gmail.com)

${ }^{2}$ Departemen Perilaku Kesehatan, Lingkungan, dan Kedokteran Sosial, Fakultas Kedokteran, Universitas Gadjah Mada
} 


\section{PENDAHULUAN}

Perkembangan penyakit HIV/AIDS menunjukkan peningkatan meskipun berbagai upaya pencegahan dan penanggulangan terus dilakukan. Semakin tinggi mobilitas penduduk antar wilayah, menyebar sentra pembangunan ekonomi, peningkatan perilaku seksual yang tidak aman dan penyalahgunaan NAPZA melalui suntikan, secara simultan memperbesar tingkat risiko penyebaran HIV/AIDS (1).

Jumlah kasus baru HIV/AIDS di Provinsi NTT setiap tahun mengalami peningkatan. Pada tahun 2013 kasus baru HIV ditemukan sebanyak 178 kasus dan AIDS sebanyak 238 kasus. Tahun 2014 kasus baru HIV meningkat menjadi 219 kasus dan tahun 2015 jumlah penderita HIV menjadi 1.865 orang dan AIDS menjadi 2.343 orang. Jumlah sebaran kasus baru HIV berdasarkan Kota/Kabupaten pada tahun 2015 paling tinggi berada di wilayah Kota Kupang sebanyak 560 kasus, kedua Kabupaten Belu sebanyak 282 kasus dan ketiga diikuti oleh Kabupaten Flores Timur dan Sikka masing-masing sebanyak 131 kasus. Kasus baru AIDS tertinggi berada pada wilayah Kabupaten Flores Timur sebanyak 386 kasus, kedua Kabupaten Sikka sebanyak 356 kasus dan peringkat ketiga Kabupaten Belu sebanyak 280 kasus (2).

HIV menginfeksi sel darah putih yang menyebabkan penurunan kekebalan tubuh manusia, sehingga mudah terkena berbagai infeksi (3). Beberapa ODHA menjadi lebih cepat lelah, mengalami demam yang tidak kunjung hilang, penurunan berat badan secara drastis hingga sering terkapar lemas di tempat tidur akibat dari infeksi HIV. Pada akhirnya mereka akan mengalami kesulitan dalam melakukan aktivitas sehari-hari bahkan mereka tidak mampu untuk bekerja lagi. Ketidakmampuan ini telah mengindikasikan bahwa mereka mengalami penurunan kualitas hidup (4).

Orang dengan HIV/AIDS (ODHA) menghadapi berbagai gejala terkait HIV dalam jangka waktu lama dan harus berjuang untuk mengatasi berbagai permasalahan sosial, kemiskinan, depresi, penyalahgunaan zat dan keyakinan budaya yang dapat memengaruhi kualitas hidup (5). WHO bekerjasama dengan UNAIDS mengusulkan peningkatan kualitas hidup harus menjadi salah satu tujuan utama dalam memberikan perawatan dan dukungan untuk ODHA (6). The World Health Organization Quality of Life (WHOQOL) dikembangkan untuk menilai kualitas hidup pasien yang sedang dalam mendapatkan perawatan kesehatan dan menilai aspek kesejahteraan pasien. Penilaian ini digunakan untuk menilai kebutuhan pasien dan untuk melakukan promosi kesehatan lanjutan sesuai kebutuhan pasien (7). Perlu dilakukan penelitian mengenai faktor yang memengaruhi kualitas hidup ODHA di Kota Kupang sebagai bahan evaluasi terhadap peningkatan kualitas hidup ODHA.

\section{METODE}

Penelitian kuantitatif ini menggunakan desain cross-sectional. Teknik pengambilan sampel mengguna- kan consecutive sampling yang melibatkan 100 orang. Penelitian dilakukan di Kota Kupang pada bulan maret 2017. Kriteria inklusi dalam penelitian ini adalah responden telah menjalani terapi ARV $\geq 1$ bulan, berusia $\geq 18$ tahun, mampu berkomunikasi dengan bahasa Indonesia dan bersedia menjadi responden dengan menandatangani informed consent. Analisis bivariat menggunakan uji chi square dan analisis multivariat menggunakan uji regresi logistik. Variabel bebas dalam penelitian ini adalah faktor sosiodemografi (jenis kelamin, usia, tingkat pendi- dikan, pekerjaan, pendapatan, status pernikahan), kepatuhan minum obat, lama terapi ARV dan stigma. Variabel terikatnya adalah kualitas hidup.

Kualitas hidup diukur dengan instrumen WHOQOLHIV BREF versi bahasa Indonesia yang telah dilakukan uji validitas dan reabilitas (8). Kepatuhan minum obat diukur dengan menggunakan instrumen AGAS (Antiretroviral General Adherence Scale), instrumen yang digunakan adalah versi Bahasa Indonesia yang sebelumnya telah dilakukan uji validitas dan reabilitas (9). Stigma diukur dengan menggunakan instrumen HASI-P (HIV/AIDS Stigma Instrument-PLWA). Instrumen yang digunakan adalah versi bahasa Indonesia yang telah diuji validitasnya (10).

\section{HASIL}

Karakteristik sosiodemografi meliputi jenis kelamin, pendidikan, pekerjaa, pendapatan, status pernikahan, kepatuhan minum obat, lama menerima terapi dan stigma responden dalam penelitian ini dapat dilihat pada Tabel 1. Tabel 1 menunjukkan lebih dari $50 \%$ responden adalah laki-laki. Sebanyak $62 \%$ responden berusia $\leq 35$ tahun. ODHA pada penelitian ini mayoritas berpendidikan tinggi, memiliki pekerjaan, pendapatan $<1.525 .000$ dan belum menikah. Penelitian ini menemukan $80 \%$ responden patuh minum obat dan 53\% menjalani terapi ARV kurang dari 2 tahun. Mayoritas ODHA mendapatkan stigma tinggi dari masyarakat. 
Tabel 1. Gambaran karakteristik sosiodemografi ODHA di Kota Kupang

\begin{tabular}{|c|c|}
\hline Variabel & $\%(n=100)$ \\
\hline \multicolumn{2}{|l|}{ Jenis kelamin } \\
\hline Laki-laki & 56 \\
\hline Perempuan & 44 \\
\hline \multicolumn{2}{|l|}{ Usia } \\
\hline$\leq 35$ Tahun & 62 \\
\hline >35 Tahun & 38 \\
\hline \multicolumn{2}{|l|}{ Pendidikan } \\
\hline Tinggi & 66 \\
\hline Rendah & 34 \\
\hline \multicolumn{2}{|l|}{ Pekerjaan } \\
\hline Bekerja & 63 \\
\hline Tidak bekerja & 37 \\
\hline \multicolumn{2}{|l|}{ Pendapatan } \\
\hline$<1.525 .000$ & 76 \\
\hline$\geq 1.525 .000$ & 24 \\
\hline \multicolumn{2}{|c|}{ Status Pernikahan } \\
\hline Belum menikah & 43 \\
\hline Menikah & 30 \\
\hline Janda/Duda & 27 \\
\hline \multicolumn{2}{|c|}{ Kepatuhan Minum Obat } \\
\hline Patuh & 80 \\
\hline Tidak patuh & 20 \\
\hline \multicolumn{2}{|l|}{ Lama Terapi ARV } \\
\hline$<2$ Tahun & 53 \\
\hline$\geq 2$ Tahun & 47 \\
\hline \multicolumn{2}{|l|}{ Stigma } \\
\hline Tidak ada stigma & 21 \\
\hline Rendah & 37 \\
\hline Tinggi & 42 \\
\hline
\end{tabular}

Berdasarkan persepsi kualitas hidup dan persepsi kesehatan ODHA didapatkan rata-rata skor kualitas hidup ODHA (Tabel 2). Menurut Persepsi ODHA, kualitas hidup yang tertinggi adalah pada domain tingkat kemandirian $(15,64)$ dan domain lingkungan $(15,21)$.

Tabel 2. Gambaran kualitas hidup, persepsi kualitas hidup dan persepsi kesehatan ODHA di Kota Kupang

\begin{tabular}{|c|c|c|c|c|}
\hline \multirow{2}{*}{$\begin{array}{l}\text { Variabel } \\
\text { Kualitas hidup }\end{array}$} & \multirow[t]{2}{*}{$\mathbf{n}$} & \multicolumn{2}{|c|}{ Mean \pm SD Min- Max } & \multirow[t]{2}{*}{$\begin{array}{l}\text { Skor yang } \\
\text { mungkin }\end{array}$} \\
\hline & & & & \\
\hline Fisik & 100 & $13,37 \pm 1,95$ & 6-17 & $4-20$ \\
\hline Psikologi & 100 & $13,33 \pm 1,90$ & $8,8-17,6$ & $4-20$ \\
\hline $\begin{array}{l}\text { Tingkat } \\
\text { Kemandirian }\end{array}$ & 100 & $15,64 \pm 2,93$ & $6-20$ & $4-20$ \\
\hline Hubungan Sosial & 100 & $14,01 \pm 2,91$ & $6-20$ & $4-20$ \\
\hline Lingkungan & 100 & $15,20 \pm 2,54$ & $7-20$ & $4-20$ \\
\hline Spiritualitas & 100 & $13,7 \pm 2,70$ & $6-19$ & $4-20$ \\
\hline $\begin{array}{l}\text { Persepsi kualitas } \\
\text { hidup } \\
\text { Persepsi }\end{array}$ & 100 & $2,59 \pm 1,11$ & $1-5$ & $1-5$ \\
\hline $\begin{array}{l}\text { kesehatan secara } \\
\text { umum }\end{array}$ & 100 & $3,72 \pm 0,87$ & $2-5$ & $1-5$ \\
\hline
\end{tabular}

Penelitian ini menunjukkan bahwa ODHA memiliki kualitas hidup yang buruk pada semua domain kualitas hidup dan persepsi secara umum, seperti Gambar 1.

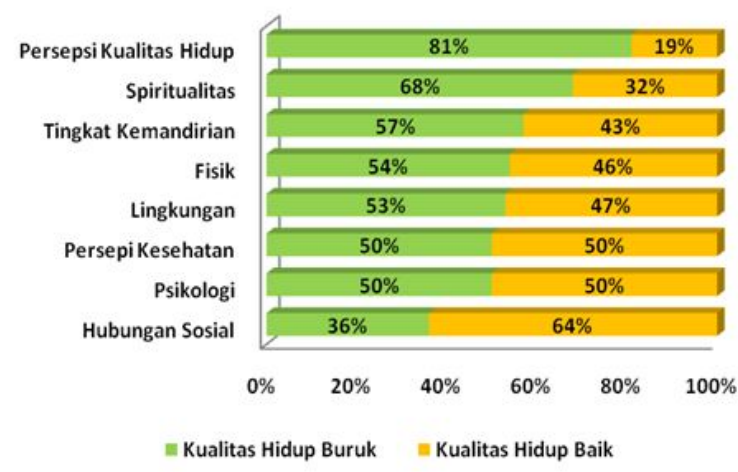

Gambar 1. Proporsi kualitas hidup ODHA

Penelitian ini tidak menemukan hubungan antara jenis kelamin, usia, pekerjaan, pendapatan, status pernikahan, dan kepatuhan minum obat dengan kualitas hidup ODHA. ODHA berpendidikan tinggi berpeluang 4,55 kali lebih besar untuk memiliki kualitas hidup baik dibandingkan ODHA berpendidikan rendah. ODHA yang terapi $\geq 2$ tahun memiliki peluang 2.91 kali lebih besar memiliki kualitas hidup lebih baik dibandingkan dengan ODHA yang terapi $\mathrm{ARV}<2$ tahun. ODHA yang tidak mengalami stigma memiliki peluang 5.57 kali lebih besar memiliki kualitas hidup baik dibandingkan dengan ODHA yang mengalami stigma tinggi.

Tabel 3. Analisis Chi-Square

\begin{tabular}{|c|c|c|c|}
\hline Variabel & $\begin{array}{l}\text { Baik } \\
\text { n(\%) }\end{array}$ & $\begin{array}{l}\text { Buruk } \\
\text { n (\%) }\end{array}$ & $\begin{array}{l}\text { OR } \\
95 \% \text { CI }\end{array}$ \\
\hline \multicolumn{4}{|l|}{ Jenis kelamin } \\
\hline Laki-laki & $30(53,6)$ & $26(46,4)$ & 1,38 \\
\hline Perempuan & $20(45,5)$ & $24(54,5)$ & $0.58-3.30$ \\
\hline \multicolumn{4}{|l|}{ Usia } \\
\hline$\leq 35$ Tahun & $30(48,4)$ & $32(51,6)$ & 1,18 \\
\hline >35 Tahun & $20(52,6)$ & $18(47,4)$ & $0.48-2.87$ \\
\hline \multicolumn{4}{|l|}{ Pendidikan } \\
\hline Tinggi & $41(62,2)$ & $25(37,8)$ & 4,55 \\
\hline Rendah & $9(26,4)$ & $25(73,6)$ & $1.69-12.79$ \\
\hline \multicolumn{4}{|l|}{ Pekerjaan } \\
\hline Bekerja & $35(55,6)$ & $28(44,4)$ & 1,83 \\
\hline Tidak bekerja & $15(40,5)$ & $22(59,5)$ & $0.74-4,5$ \\
\hline \multicolumn{4}{|l|}{ Pendapatan } \\
\hline$\geq 1.525 .000$ & $15(62,5)$ & $9(37,5)$ & 1,95 \\
\hline$<1.525 .000$ & $35(46,1)$ & $41(53,9)$ & $0.69-5.69$ \\
\hline \multicolumn{4}{|l|}{ Status pernikahan } \\
\hline Belum menikah & $23(53,5)$ & $20(46,5)$ & 1,87 \\
\hline Menikah & $12(40)$ & $18(60)$ & $0.57-6.12$ \\
\hline Janda/ Duda & $15(55,6)$ & $12(44,4)$ & \\
\hline \multicolumn{4}{|c|}{ Kepatuhan minum obat } \\
\hline Patuh & $42(52,5)$ & $38(47,5)$ & 1,65 \\
\hline Tidak & $8(40)$ & $12(60)$ & $0.55-5,19$ \\
\hline \multicolumn{4}{|l|}{ Lama Terapi ARV } \\
\hline$<2$ Tahun & $17(36,2)$ & $30(63,8)$ & 2,91 \\
\hline$\geq 2$ Tahun & $33(62,3)$ & $20(37,7)$ & $1.19-7.13$ \\
\hline \multicolumn{4}{|l|}{ Stigma } \\
\hline \multirow[t]{2}{*}{ Tidak ada } & $15(71,4)$ & $6(28,7)$ & 5,57 \\
\hline & & & $1.55-21.2$ \\
\hline \multirow[t]{2}{*}{ Rendah } & $22(59,5)$ & $15(40,5)$ & 3,27 \\
\hline & & & $1.17-9.18$ \\
\hline Tinggi(references) & $13(30,9)$ & $29(69,1)$ & \\
\hline
\end{tabular}


Faktor yang paling berpengaruh terhadap kualitas hidup ODHA secara berurutan adalah pendidikan, tidak ada stigma, lama terapi ARV, dan stigma rendah (Tabel 4.).

Tabel 4. Analisis Regresi Logistik Faktor yang Paling Berpengaruh Terhadap Kualitas Hidup ODHA di Kota Kupang

\begin{tabular}{lcrrr}
\hline \multirow{2}{*}{ Variabel } & \multirow{2}{*}{ OR } & \multirow{2}{*}{ p-value } & \multicolumn{2}{c}{ 95\% CI } \\
\cline { 4 - 5 } & & & Lower & Upper \\
\hline Pendidikan & 4.82 & 0.002 & 1.77 & 13.16 \\
Lama Terapi ARV & 3.04 & 0.018 & 1.20 & 7.64 \\
Stigma & & & & \\
Tidak ada & 4.59 & 0.015 & 1.34 & 15.76 \\
Rendah & 2.81 & 0.045 & 1.02 & 7.76 \\
\hline
\end{tabular}

\section{BAHASAN}

Penelitian ini menunjukkan bahwa tidak ada hubungan yang signifikan antara jenis kelamin, usia, pekerjaan, pendapatan, status pernikahan dan kepatuhan minum obat dengan kualitas hidup ODHA. Hasil penelitian ini berbeda dengan penelitian yang telah dilakukan sebelumnya yang menjelaskan bahwa jenis kelamin, status pernikahan, usia, status pekerjaan, tingkat pendapatan dan kepatuhan minum obat memiliki hubungan yang signifikan terhadap kualitas hidup ODHA $(8,11,12)$.

Pendidikan merupakan faktor sosiodemografi yang berhubungan secara signifikan dengan kualitas hidup. ODHA dengan tingkat pendidikan tinggi memiliki kualitas hidup yang tinggi dan sebaliknya (12). Tingkat pendidikan dapat memengaruhi keterampilan manajemen diri untuk menghadapi penyakit dan berbagai permasalahan lain. Orang berpendidikan memiliki kemudahan untuk mengakses dan memahami informasi yang diperoleh (13). Tingkat pendidikan dapat meningkatkan kemampuan pasien untuk melakukan pemecahan masalah dan pengambilan keputusan secara aktif, terkait dengan penyakitnya (14).

Hasil penelitian menunjukkan terdapat hubungan antara pengetahuan dengan perubahan perilaku pasien HIV/AIDS. Semakin tinggi pengetahuan, semakin tinggi peluang perubahan perilaku terjadi, dan sebaliknya (15). Tingkat pendidikan sering dikaitkan dengan status ekonomi. ODHA yang berpendidikan tinggi mungkin memiliki penghasilan lebih baik dan hidup dalam kondisi yang lebih baik (16). Penghasilan yang tinggi meningkatkan kemampuan ODHA dalam membiayai pengobatan dan perawatan diri (17).

Penelitian ini menunjukkan hubungan signifikan antara variabel lama terapi ARV dengan kualitas hidup ODHA. Penggunaan ARV pada pasien HIV merupakan upaya untuk memperpanjang umur harapan hidup. ARV bekerja melawan infeksi dengan cara memperlambat reproduksi HIV dalam tubuh. ARV efektif digunakan dalam bentuk kombinasi, bukan untuk menyembuhkan, tetapi untuk memperpanjang hidup ODHA, membuat mereka lebih sehat dan lebih produktif dengan mengurangi viremia dan meningkatkan jumlah sel-sel CD4 (18). ODHA yang telah lama mengonsumsi ARV mengalami peningkatan skor kualitas hidup (19). ARV terbukti memperpanjang umur harapan hidup ODHA, menjaga kesehatan fisik, serta meningkatkan manajemen penyakit (20). Untuk mencapai supresi virologis yang baik diperlukan tingkat kepatuhan terapi ARV yang sangat tinggi (minimal 95\%). Tingkat kepatuhan terapi ARV masih rendah. Hal tersebut terjadi karena faktor biaya berobat, efek samping obat, dan stigma (21). Stigma dan diskriminasi yang berkembang di masyara- kat, tenaga medis, teman maupun keluarga akan memperburuk kondisi pasien. Penderita HIV/AIDS sering mendapat perlakuan yang tidak baik setelah mereka dinyatakan positif mengidap HIV/AIDS (22).

Stigma adalah sikap atau attitude negatif yang terkait dengan keyakinan atau pengetahuan seseorang. Diskriminasi adalah perilaku atau tindakan yang dilakukan. Stigma dan diskriminasi terlahir dari pandangan negatif terhadap orang atau kelompok tertentu yang dianggap mempunyai sesuatu yang tidak baik (23). Stigma membuat ODHA mudah merasa bersalah dan menerima penolakan lingkungan. Diskriminasi dapat terjadi pada di masyarakat sekitar tempat tinggal, maupun di tempat kerja (24).

Hasil penelitian ini menunjukkan hubungan yang signifikan antara stigma dengan kualitas hidup ODHA. Seperti yang dijelaskan oleh Said, stigma HIV/AIDS menjadi salah satu penyebab menurunnya kualitas hidup ODHA (25). Terdapat 21 ODHA yang tidak memiliki stigma. Hal ini terjadi karena ODHA belum membuka diri tentang statusnya. Stigma menjadi penghalang ODHA untuk mengungkap status. Lebih lanjut, hal tersebut dapat berdampak pada perilaku pencegahan HIV, perilaku mencari perawatan HIV, serta kualitas untuk perawatan dan pengobatan pada ODHA. Perlu program pencegahan dan pengobatan HIV untuk mengurangi stigma HIV/AIDS (26).

Stigma berdampak pada kualitas hidup ODHA, sehingga perlu upaya pengembangan program promosi kesehatan untuk menurunkan stigma baik dari level keluarga, masyarakat, maupun institusional. Beberapa intervensi yang dapat dilakukan untuk mengurangi stigma yang ada di masyarakat adalah dengan mengubah sikap individu terhadap ODHA melalui kampanye 
media yang mempromosikan toleransi dan kasih sayang (27). Pelatihan untuk orangtua secara signifikan berdampak untuk mengurangi stigma terkait HIV dan isolasi sosial. Intervensi ini membantu orangtua untuk dapat mengajarkan kepada anak-anak tentang keterampilan untuk berinteraksi dengan ODHA serta pencegahan terhadap risiko HIV/AIDS (28). Dukungan sosial meningkatkan kepercayaan diri ODHA dan meningkatkan kepatuhan terapi ARV. Pada akhirnya, ODHA dapat memberdayakan diri sendiri dan meningkatkan mutu hidup.

\section{SIMPULAN}

Terdapat hubungan signifikan tingkat pendidikan, lama terapi ARV, dan stigma dengan kualitas hidup ODHA. ODHA yang memiliki kualitas hidup baik adalah ODHA dengan pendidikan tinggi, tidak ada stigma, lama terapi $\mathrm{ARV} \geq 2$ tahun, dan stigma rendah.

\begin{abstract}
Abstrak
Tujuan: Penelitian ini bertujuan untuk menge- tahui faktor yang memengaruhi kualitas hidup orang Dengan HIV/AIDS (ODHA) di Kota Kupang. Metode: Penelitian ini menggunakan desain cross sectional pada 100 orang responden dengan karakteristik telah menjalani terapi obat anti- retroviral (ARV) $\geq 1$ bulan, berusia lebih dari $\geq 18$ tahun, mampu berkomunikasi dengan bahasa Indonesia, dan bersedia menjadi responden. Analisis bivariat menggunakan uji chi square dan analisis multivariat menggunakan analisis regresi logistik. Hasil: Tidak ada hubungan yang yang signifikan antara tingkat pendidikan, lama terapi ARV dan stigma dengan kualitas hidup ODHA. Tidak ada hubungan yang signifikan antara jenis kelamin usia, pekerjaan, pendapatan, status pernikahan dan kepatuhan minum obat dengan kualitas hidup ODHA. Faktor yang paling berpengaruh terhadap kualitas hidup ODHA secara berurutan adalah tingkat pendidikan diikuti oleh lama terapi ARV dan stigma. Simpulan: Faktor yang paling berpengaruh terhadap kualitas hidup ODHA secara berurutan adalah tingkat pendidikan diikuti oleh lama terapi ARV dan stigma.
\end{abstract}

Kata kunci: lama terapi ARV; stigma; kualitas hidup; Orang dengan HIV/AIDS

\section{PUSTAKA}

1. Dinkes Provinsi NTT. Profil Kesehatan Provinsi Nusa Tenggara Timur Tahun 2014. Provinsi NTT; 2014.

2. Dinkes Provinsi NTT. Profil Kesehatan Provinsi Nusa Tenggara Timur Tahun 2015. Provinsi NTT; 2015.

3. Kementerian Kesehatan RI. Situasi dan Analisis HIV AIDS. Kemenkes RI. Jakarta; 2014.

4. Diatmi K, Fridari D. Hubungan Antara Dukungan Sosial dengan Kualitas Hidup pada Orang Dengan HIV dan AIDS (ODHA) Di Yayasan Spirit Paramacitta. Jurnal Psikologi Udayana. 2014;1(2):353-62.

5. Basavaraj KH, Navya MA, Rashmi R. Quality of life in HIV/AIDS. Indian journal of sexually transmitted diseases. 2010 Jul;31(2):75.

6. Sun W, Wu M, Qu P, Lu C, Wang L. Quality of life of people living with HIV/AIDS under the new epidemic characteristics in China and the associated factors. PloS one. 2013 May 31;8(5):e64562.

7. World Health Organization. WHOQOL-BREF: Introduction, Administration, Scoring And Generic Version Of The Assessment: : Field Trial Version [Internet]. Geneva, Switzerland; 1996.

8. Oktavia N. Faktor-Faktor Yang memengaruhi Kualitas Hidup Penderita HIV/AIDS di Kabupaten Boyolali dan Kota Surakarta (Solo) Provinsi Jawa Tengah Tahun 2012. Universitas Gadjah Mada Yogyakarta; 2012.

9. Fitriawan AS. Faktor-Faktor Yang memengaruhi Kepatuhan Menjalankan Antiretroviral Therapy (ART) Pada Pasien HIV/AIDS Yang Melakukan Rawat Jalan Di RSUP Dr.Sardjito Yogyakarta. Skripsi program studi keperawatan Universitas Gadjah Mada. Universitas Gadjah Mada; 2012.

10. Hastuti S. Pengaruh Stigma HIV/AIDS Terhadap Kepatuhan Pemakaian Kondom Pada Pria ODHA. Universitas Gadjah Mada; 2011.

11. Nojomi M, Anbary K, Ranjbar M. Health-Related Quality of Life in Patients with HIV/AIDS. J Arch Iran Med. 2008;11(6):608-12.

12. Khumsaen N, Aoup-por W, Thammachak $P$. Factors influencing quality of life among people living with HIV (PLWH) in Suphanburi Province, Thailand. Journal of the Association of Nurses in AIDS Care. 2012 Jan 1;23(1):63-72.

13. Costa TL, Oliveira DC, Gomes AM, Formozo GA. Quality of life and people living with AIDS: relationship with sociodemographic and health aspects. Revista latino-americana de enfermagem. 2014 Aug;22(4):582-90.

14. Nirmal B, Divya K, Dorairaj V, Venkateswaran K. Quality of Life in HIV/AIDS Patients: A Cross-sectional Study in South India [Internet]. Indian Journal of Sexually Transmitted Disease and AIDS. 2008. p. 15.

15. Wahyuni A. Faktor-Faktor Yang memengaruhi Perubahan Perilaku Pasien HIV/AIDS. Human Care Journal. 2016 Jun 27;1(2).

16. Feng M, Feng J, Yu C, Chen L, Yang P-H, Shih C-C, et al. Stress, needs, and quality of life of people living with human immunodeficiency virus / AIDS in Taiwan. Kaohsiung J Med Sci [Internet]. Published by Elsevier Taiwan LLC; 2015;31(9):485-92.

17. Sulaeman ES, Murti B, Waryana W. Aplikasi Model PRECEDE-PROCEED Pada Perencanaan Program 
Pemberdayaan Masyarakat Bidang Kesehatan Berbasis Penilaian Kebutuhan Kesehatan Masyarakat. YARSI Medical Journal. 2017 May 2;23(3):149-64.

18. Yuniar Y, Handayani RS, Aryastami NK. Faktor-faktor Pendukung Kepatuhan Orang dengan HIV AIDS (ODHA) dalam Minum Obat Antiretroviral di Kota Bandung dan Cimahi. Buletin Penelitian Kesehatan. 2013 Dec 8;41(2 Jun):72-83.

19. Bakiono F, Guiguimdé PW, Sanou M, Ouédraogo L, Robert A. Quality of life in persons living with HIV in Burkina Faso: a follow-up over 12 months. BMC public health. 2015 Dec;15(1):1119.

20. Holtz C, Sowell R, VanBrackle L, Velasquez G, Hernandez-Alonso V. A quantitative study of factors influencing quality of life in rural Mexican women diagnosed with HIV. Journal of the Association of Nurses in AIDS Care. 2014 Nov 1;25(6):555-67.

21. Sugiharti S, Yuniar Y, Lestary H. Gambaran Kepatuhan Orang Dengan Hiv-aids (Odha) Dalam Minum Obat Arv Di Kota Bandung, Provinsi Jawa Barat, Tahun 2011-2012. Jurnal Kesehatan Reproduksi. 2014;5(2):113-23.Armiyati Y, Rahayu DA, Aisah S. Manajemen Masalah Psikospiritual
Pasien HIV/AIDS di Kota Semarang. 2nd Univ Res Coloquium. 2015; ISSN 2407-:548-56.

22. Muma R., Lyons A., Borweki M. HIV: Manual Untuk Tenaga Kesehatan. Jakarta: EGC; 1997.

23. Said S. Stigma HIV/AIDS dan Kualitas Hidup Orang Dengan HIV/AIDS di Yogyakarta. Universitas Gadjah Mada; 2014.

24. Sengupta S, Banks B, Jonas D, Miles MS, Smith GC. HIV interventions to reduce HIV/AIDS stigma: a systematic review. AIDS and Behavior. 2011 Aug 1;15(6):1075-87.

25. Parker RG, Aggleton P, Attawell K, Pulerwitz J, Brown L. HIV/AIDS-related stigma and discrimination: A conceptual framework and an agenda for action. New York: Population Council; 2002 May.

26. Krauss BJ, Godfrey CC, O’day J, Freidin E. Hugging my uncle: the impact of a parent training on children's comfort interacting with persons living with HIV. Journal of pediatric psychology. 2006 Feb 1;31(9):891-904

27. Burhan R. Pemanfaatan pelayanan kesehatan oleh perempuan terinfeksi HIV/AIDS. Kesmas: National Public Health Journal. 2013 Aug 1;8(1):33-8. 